\title{
Analysis of Specie - Treatment - Adhesive Combinations for Glulam Purpose
}

\author{
Carlito Calil Neto ${ }^{1}$, André Luis Christoforo ${ }^{2, *}$, Francisco Antonio Rocco Lahr ${ }^{1}$, Carlito Calil Júnior ${ }^{1}$ \\ ${ }^{1}$ Department of Structural Engineering, Engineering School of São Carlos (EESC/USP), São Carlos, 13566-590, Brazil \\ ${ }^{2}$ Department of Civil Engineering, Federal University of São Carlos, São Carlos, 13565-905, Brazil
}

\begin{abstract}
Glued Laminated Timber is an engineered product that requires precision of manufacturing in all its stages. The finished product can only be tested under laboratory conditions, however it is necessary to quality control in their production to ensure that the properties of the Glulam are appropriate to the product specified requirements in accordance with specified for the product in accordance with the standards. This paper evaluates the proposed trials conducted with combinations of three Brazilian reforestation species, two adhesive and three types of treatment, used in of Research and Development CPFL/EESC "PD220-07 - Head of Series Crosshead. The combination that showed the best performance was Pine wood with any type of adhesive or treatment discussed, so it can be used in external mode. Lyptus wood for any combination of patch treatment fall into internal use class. Teak wood can be used indoors (adhesive Purbond and all kinds of treatment) or external (Cascophen adhesive and all kinds of treatment).
\end{abstract}

Keywords Glulam, Reforestation species, Treatment, Adhesive, Combinations

\section{Introduction}

Glued Laminated Timber (Glulam) is an engineered wood product that requires precision of manufacturing in all its stages. The finished product can only be tested under laboratory conditions, however, quality control is required in the production to ensure that the properties of Glulam are appropriate to the resistance specified for the material by standards.

In this work, test methods and results for quality control of amendments in the face (shear in the glue line), creep test and delamination are presented. These tests were performed at LaMEM (Wood and Timber Structures Laboratory), São Carlos Engineering School, São Paulo University, in Brazil, in order to evaluate some combinations adhesive/wood species/treatment according to ANSI/AITC[1-3] specifications. Three reforestation species were used: Pinus, Lyptus and Teak; three treatments: CCA, CCB Ox, CCB Salt and no treatment; two adhesives: Purbond HB S309, Cascophen RS 216M. (Ox: Oxide: it is made with raw materials based on pure oxides, which guarantee the quality of a product with perfect percentages and the homogenization of the ingredients; Salt: comes down to a simple mixture of compounds in the form of salts, causing problems fixing Boron).

* Corresponding author:

alchristoforo@yahoo.com.br (André Luis Christoforo)

Published online at http://journal.sapub.org/ijme

Copyright (C) 2014 Scientific \& Academic Publishing. All Rights Reserved
Pinus species have been introduced in Brazil for more than a century for varied purposes [4]. Many of them were brought in by Europeans as curiosity, for ornamental purposes and for timber production. The first introductions that have news were Pinus canariensis, from the Canary Islands, in Rio Grande do Sul, in the 1880s. By 1936, the first trials were initiated to introduce Pinus silviculture purposes, with European species. However, there was no success, due to poor adaptation to our climate. Only in 1948, through the Forest Service of the State of São Paulo, were introduced to test the American species known in the sources as "yellow pine" which include $P$. palustris, $P$. echinata, $P$. elliottii and $P$. taeda. Among these, the last two stand out for the ease in cultivation, the rapid growth and reproduction intense in the South and Southeast of Brazil. Since then a large number of species continued to be introduced and established in field experiments by government agencies and private companies seeking to establish commercial plantations. The diversity of species and geographical races tested, from not only the United States but also in Mexico, Central America, the Caribbean Islands and Asia was essential so that one could draw a profile of the developmental characteristics of each species to facilitate plantings trade in various ecological sites in the country.

The Pinus Oocarpa is among the tropical pine species most widespread in the tropics. It is native to Mexico and Central America, with more extensive natural distribution in the direction northwest-southeast between Pinus region. The best performance is obtained this species in the highlands, especially in the "Cerrado", given its drought tolerance. The 
wood is moderately hard and resistant, high-quality production of sawn pieces for buildings and making plates. Apart from wood, P. oocarpa also produces resin amount feasible for commercial extraction. This species produces many seeds, which facilitates the expansion of its plantations. In areas of low altitude or coastal plain, this species grows slowly, with poor stem form, and become susceptible to various diseases.

Lyptus ${ }^{\circledR}$ is a wood considered noble, fully extracted from renewable forests from trees planted, which ensures a reliable supply, and environmentally sustainable. This is one of its main advantages over hardwoods traditional, such as mahogany, rosewood, ivory and walnut. Besides being environmentally friendly, wood Lyptus ${ }^{\circledR}$ is developed by crossing selected trees, which give more versatility, durability and beauty. So you can opt for a hardwood, without running the risk of damaging the environment and without paying more for it, because, despite all the study, management and dedication that Lyptus ${ }^{\circledR}$ requires, this is not reflected in being value final consumer, with a cost equivalent to that of other hardwoods[5].

The wood of Tectona grandis, whose names are popular Teak, Teak and Djati, can only be cultivated in tropical areas, but has great demand, especially in Europe, surpassing prices Mahogany. The teak wood is used primarily in the manufacture of window frames, due to their weather resistance. It is also used in the production of furniture, vessels and decorations. It is a wooden stable, virtually no warping and some contracts during drying and resist to changes in humidity. This is an essential property in the case of doors, windows, drawers and allowing them to open, and close smoothly without difficulty. Teak is durable, because his heart is not attacked by termites, beetles and other insects. It is immune to the action of wood decay fungi and may be buried, exposed to weather or sea water without damage. The durability of the core due to "tectoquinona" a natural preservative contained in the wood cells. Any sapwood, as the core of Teak contains another substance, referred to as "rubber", a kind of latex which reduces the absorption of water and lubricates the surface, reducing abrasion. Another feature of Teak is resistance to acids and protecting the iron nails and screws from corrosion. Medium texture and glossy surface, the Teak wood can be sawn, planed, sanded and drilled without difficulty. It has a low rate of cracks and allows neat finish. Although not oily presents difficulties in gluing. The heart is freshly cut green, changing to golden yellow or brown when exposed to light and air.

To keep two surfaces together is a work of art. There are several types of adhesives, choosing the right one depends the materials you want to glue.

The properties of wood have a clear effect on the adhesive. Hardwoods are generally more difficult than softwood. The anatomical properties of wood have a significant influence on the bonding of wood, such as the variability in density and porosity, heartwood and sapwood and juvenile wood and mature wood. Furthermore, there is the influence of the dimensional instability of reaction wood, as well as the direction of the grain, in which the penetration relates to the cutting direction.

Whereas the anatomical properties of wood, relevant faces of their effect on movement of the adhesive into the wood structure, i.e. on the penetration.

Among the species are differences in the growth pattern of each tree. During the growing season, are formed in different cell types and sizes, that depending on demand genetically conducted, which changes over time. So, growth rings are formed where large cells are formed in the early wood and latewood cells in robust.

Some trees exhibit a uniform growth throughout the growing season, therefore producing fewer distinct rings. A feature to be consider in hardwood timber is the profile of growth rings, which consists of: ring porous, diffuse, and semi-diffuse, abrupt or gradual transition between early and late wood of conifers.

The adhesive should be chosen considering the weather conditions of use (use classes), the species of wood, the preservative used and manufacturing methods.

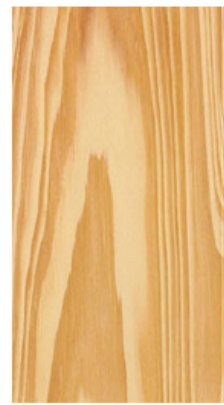

(a)

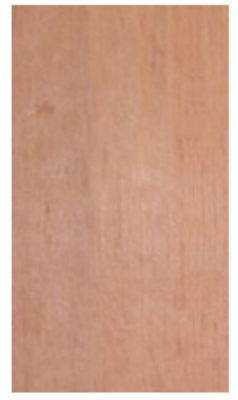

(b)

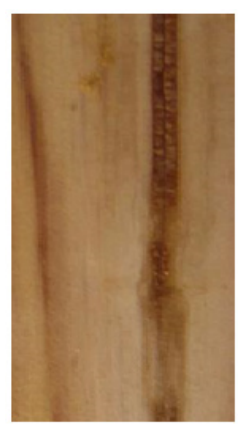

(c)

Figure 1. Pine (a), Lyptus (b) and Teak (c) wood

Table 1. Use Classes

\begin{tabular}{ccccc}
\hline $\begin{array}{c}\text { Use } \\
\text { Classes }\end{array}$ & Description & $\begin{array}{c}\text { Moisture of the } \\
\text { wood }\end{array}$ & Temperature & $\begin{array}{c}\text { Type of } \\
\text { adhesive }\end{array}$ \\
\hline 1 & $\begin{array}{c}\leq 12 \% \\
\text { Interior } \\
\text { Exterior }\end{array}$ & $\begin{array}{c}\leq 18 \% \text { for wood } \\
\text { without } \\
\text { treatment }\end{array}$ & $<50^{\circ} \mathrm{C}$ & I \\
& Covered & $\begin{array}{c}\leq 20 \% \text { for } \\
\text { softwoods with } \\
\text { treatment }\end{array}$ & $<50^{\circ} \mathrm{C}$ & I \\
\hline 3 & Exterior & Any & Any & I I \\
\hline
\end{tabular}

According to NCh2148.cR2010, the use classes in which the structural elements are laminated may fall according 
shows Table 1.

The preservation of woods consists in impregnating wood with toxic substances, so that they can no longer be used as food for their survival and multiplication of termites.

However, to date, not found a wood preservative that is highly toxic to wood decay organisms and completely harmless to other animals. The substances of low toxicity to warm-blooded animals also have low efficiency as preservatives for wood and those with good efficiency as preservatives; also have some degree of toxicity to humans.

The preservative must present a compromise between efficiency and safety. It should be efficient, but at the same time, must present minimum risk to his manipulator.

A Wood preservative is any chemical substance that poisons of the wood cell nutrients, making them resistant to attack and development of wood decay organisms. Below are described some properties necessary that the wood preservatives must submit[6]:

- Toxicity to a large number of xylophages organisms;

- low toxicity to non-wood decay organisms;

- sustained action;

- high fixation on wood;

- do not change the characteristics of the wood;

- avoid altering the materials that are in contact with the wood;

- preferably be colorless, odorless and tasteless;

- inflammable;

- economical and easy to obtain in the market.

Hardly find a condom that combines all these features, however depending on the type of material to be treated, only some of these features are needed.

In accordance with Chilean standard (NCh2148.cR2010), the preservative treatment on glued laminated wood must be performed after its manufacturing, checking the compatibility between the adhesive and the treatment to be used. When the dimensions become thinner MLC treatment impossible, you should use preserved wood for their manufacture, the moisture content of wood in its assembly must be controlled and it should also check the compatibility of preservative used with the adhesive. So should follow the recommendations of the manufacturers of preservative and adhesive for their compatibility.

\section{Methods}

This work was conducted with the project's Research and Development CPFL/EESC: "PD220-07 - Head of Series Crosshead," In the development of this work were produced from three species of Brazilian wood reforestation is a conifer Pinus sp and two teak and hardwood Lyptus. The three species passed thru a visual and mechanical classification, so that they could be assembled for Glulam propose.

The visual rating is based on the premise that the mechanical properties can be viewed and judged by the human eye. With the help of classification rules, the growth characteristics are used to select the timber classes of visual quality.

To perform the visual grading of pine wood according to the criteria adopted by the Brazilian standard NBR 7190[7].

As for the teak wood tried to adapt this criterion for classification, because there is no visual grading criteria that specify the dimensions to be checked in hardwoods timber.

According to Ross and Pellerin (1994)[8], the fundamental hypothesis for the nondestructive evaluation (Figure 2) of wood was initiated by Jayne (1959). He proposed that the stored energy and dissipation properties of the wood would be measured by non-destructive means, determining the static behavior of the timber. As a consequence, convenient mathematical relationships between these properties and the static properties of strength and elasticity could be achieved through statistical regression analysis.

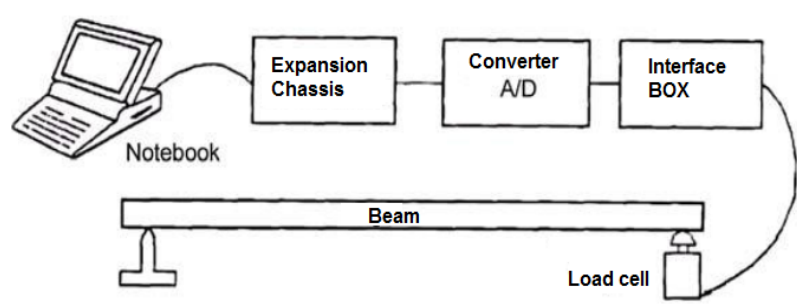

Figure 2. Nondestructive evaluation

The assembly process was the same for all species. The average moisture content of the plates used was $12 \%$. The bonding was made with layers of wood without treatment using the two types of adhesives.

Glue dosage used was that specified by the manufacturer (single line): 180 to $200 \mathrm{~g} / \mathrm{m}^{2}$ and pressure of $10 \mathrm{MPa}$.

After the assembly, wood pieces were treated with preservative-based CCA, CCB and CCBS, the most commonly used in Brazil. Chemical treatment was carried out in an autoclave after seven days of adhesive curing, air-conditioned to a relative humidity of $12 \%$.

Test methods followed ANSI/AITC A190[9] specifications. The tests related to the CSA 0112.10[10] standard (delamination and creep test) were performed by adjusting the conditions of such recommendations crosses under study[11-14].

The plate nominal dimensions were $210 \mathrm{~cm}$ long, $10 \mathrm{~cm}$ wide and $4 \mathrm{~cm}$ thick.

Six specimens were removed from each crosses, one for the creep test, two for shear test and three for delamination test, as shown in Figure 3.

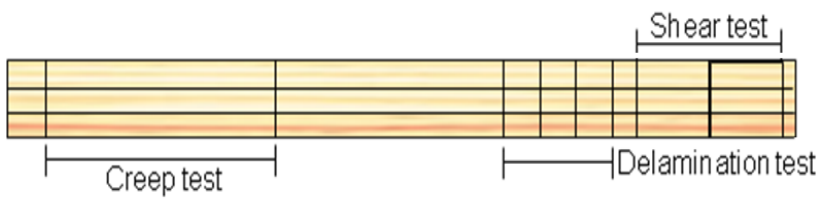

Figure 3. Analysis model

After cutting the specimens for the delamination test go to the preservative tank where the beginning of the cycle of 
delamination. The shear specimens were then prepared (Figure 4) to be sheared, one of which first lower left 48 hours in water.

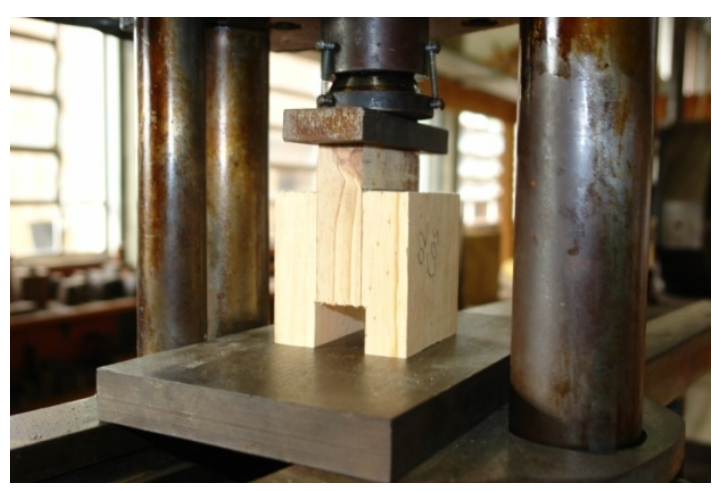

Figure 4. Shear test

For the creep test (Figure 5), the specimens were adapted according to the dimensions of the crosses produced.
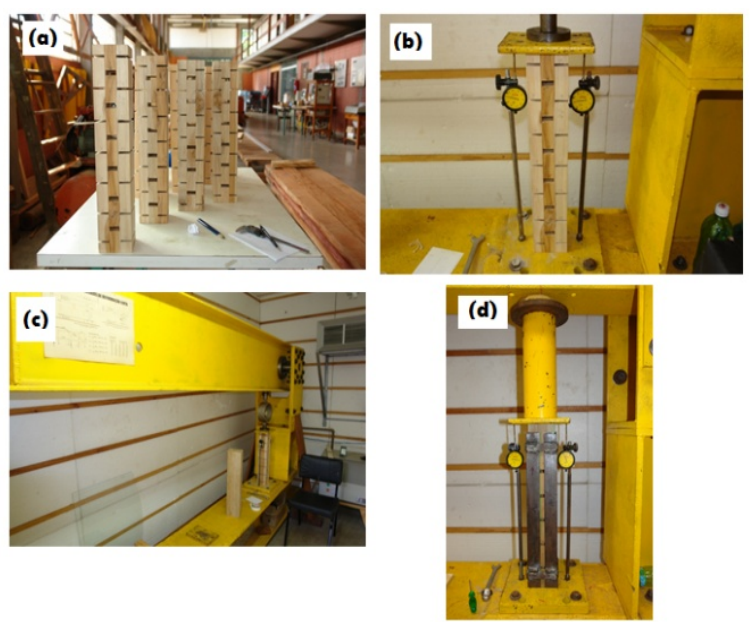

Figure 5. Creep test

At first we faced some troubles regarding instability (Figure 6), therefore an iron mask was made to reduce it.

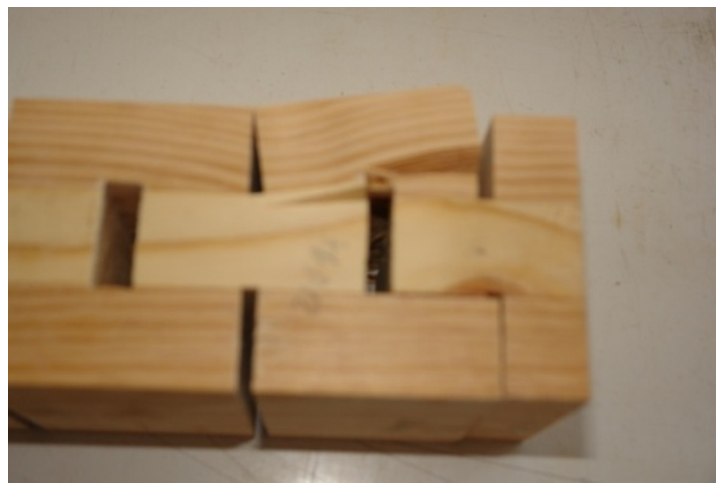

Figure 6. Instability creep test

Eighteen crosses were produced for each wood species, nine for each type of adhesive, a total of fifty four crosses of three species of Glulam reforested wood, with two types of adhesives and three types of treatment (CCA, CCB and CCBS). The experimental planning is show in Table 2,
Table 2. Planning for testing

\begin{tabular}{|c|c|c|c|}
\hline \multirow{18}{*}{$\begin{array}{c}54 \\
\text { CrossHeads }\end{array}$} & \multirow{6}{*}{ Sp. 1} & \multirow{3}{*}{ Adh. A } & Treat.A \\
\hline & & & Treat.B \\
\hline & & & Treat.C \\
\hline & & \multirow{3}{*}{ Adh. B } & Treat.A \\
\hline & & & Treat.B \\
\hline & & & Treat.C \\
\hline & \multirow{6}{*}{ Sp. 2} & \multirow{3}{*}{ Adh. A } & Treat.A \\
\hline & & & Treat.B \\
\hline & & & Treat.C \\
\hline & & \multirow{3}{*}{ Adh. B } & Treat.A \\
\hline & & & Treat.B \\
\hline & & & Treat.C \\
\hline & \multirow{6}{*}{ Sp. 3} & \multirow{3}{*}{ Adh. A } & Treat.A \\
\hline & & & Treat.B \\
\hline & & & Treat.C \\
\hline & & \multirow{3}{*}{ Adh. B } & Treat.A \\
\hline & & & Treat.B \\
\hline & & & Treat.C \\
\hline
\end{tabular}

were:

Sp.1: Pine Specie;

Sp.2: Lyptus Specie;

Sp.3: Teak Specie;

Adh. A: Cascophen Adhesive;

Adh. B: Purbond Adhesive;

Treat A: CCA treatment;

Treat B: CCB Ox treatment;

Treat C: CCB Salt treatment.

The criteria to be considered for the "use classes" for acceptance of combination-type adhesive-preservative treatment as following:

- for the delamination test the 0112.10 CSA Standard describes that the delamination of glue all lines of the specimen should not exceed $1 \%$.

- for the shear test, the coefficient of variation assume is $28 \%$, similar to that prescribed by the Brazilian Standard NBR 7190. Failure mode must be considered.

- the creep test presented several problems with specimen instability and some with failure mode for bending moment, believed to be caused by the difficulty of adaptation, much greater than that recommended by the Canadian standard CSA 0112.10. The results were not satisfactory.

- Specimens with total break in adhesive line due to the dry conditions were considered substandard.

- Specimens with total break in the line of adhesive in wet condition were classified as a class for "internal use".

\section{Results and Discussions}

For the creep test, was made two tables and a graphic that show the specimen behavior (Figure 7). Below are presented the results obtained in one experimental tests performed with the creep combination pine - Cascophen - no treatment.

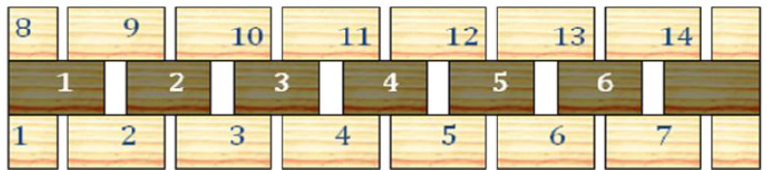

Figure 7. Creep specimen lines 
Table 3. Creep test

\begin{tabular}{cccccccc}
\hline \multicolumn{3}{c}{ Before } & \multicolumn{5}{c}{ After } \\
\hline \multicolumn{3}{c}{ Cascophen } \\
\hline $\begin{array}{c}\text { Lateral Line } \\
(\mathrm{mm})\end{array}$ & \multicolumn{1}{c}{ Central Line $(\mathrm{mm})$} & \multicolumn{2}{c}{$\begin{array}{c}\text { Lateral Line } \\
(\mathrm{mm})\end{array}$} \\
1 & 6.27 & 1 & 12.3 & 1 & 5.92 & 1 & 12.16 \\
2 & 7.22 & 2 & 12.5 & 2 & 6.99 & 2 & 12.25 \\
3 & 6.42 & 3 & 12.49 & 3 & 6.22 & 3 & 12.37 \\
4 & 6.22 & 4 & 12.52 & 4 & 6.13 & 4 & 12.45 \\
5 & 6.15 & 5 & 12.83 & 5 & 6.09 & 5 & 12.25 \\
6 & 6.32 & 6 & 12.4 & 6 & 6.08 & 6 & 12.21 \\
7 & 6.44 & & & 7 & 6.34 & & \\
8 & 7.30 & & & 8 & 6.78 & & \\
9 & 5.96 & & & 9 & 5.84 & & \\
10 & 5.63 & & & 10 & 5.49 & & \\
11 & 6.35 & & & 11 & 6.13 & \\
12 & 6.58 & & & 12 & 6.42 & \\
13 & 6.44 & & & 13 & 6.36 & \\
14 & 5.78 & & & 14 & 5.79 & \\
\hline
\end{tabular}

The results showed that Pine wood with any type of adhesive or treatment discussed because the delamination tests was under $1 \%$ as the standard determines, the standard deviation was under 1.17 , the coefficient of variation was under $28 \%$ as the standard NBR 7190 determines, the rupture mode was all in wood and the behavior under water was good also; so it can be used in external mode.

Lyptus wood, for any combination, falls into internal use class because the delamination tests exceed the $1 \%$ as the standard determines, the standard deviation was over 117 , the coefficient of variation was over $28 \%$ as the standard NBR 7190 determines, the rupture mode was most in adhesive and the behavior under water was not good.

Teak wood can be used indoors (adhesive Purbond and all types of treatment) and outdoors (Cascophen adhesive and all types of treatment), because the delamination tests with Purbond and Cascophen was over $1 \%$ as the standard determines but the coefficient of variation was over $28 \%$ with Purbond adhesive above and under water as the NBR 7190 determines, the rupture mode was on wood and the behavior was really good.

Table 4. Creep test track

\begin{tabular}{|c|c|c|c|c|c|c|c|c|c|}
\hline \multicolumn{3}{|c|}{$\begin{array}{c}\text { Date } \\
\text { (day/month/year) }\end{array}$} & \multicolumn{3}{|c|}{$\begin{array}{c}\text { Time } \\
\text { (hour } / \text { min) }\end{array}$} & \multirow{2}{*}{$\begin{array}{c}\begin{array}{c}\text { Moisture } \\
(\%)\end{array} \\
64\end{array}$} & \multirow{2}{*}{$\begin{array}{c}\text { Temperature } \\
(\square \mathrm{C})\end{array}$} & \multirow{2}{*}{$\begin{array}{c}\begin{array}{c}\text { Displacement } \\
\text { (Left Side) }\end{array} \\
134\end{array}$} & \multirow{2}{*}{$\begin{array}{c}\begin{array}{c}\text { Displacement } \\
\text { (Right Side) }\end{array} \\
136\end{array}$} \\
\hline 6 & 5 & 10 & 9 & 0 & am & & & & \\
\hline 6 & 5 & 10 & 9 & 30 & $\mathrm{am}$ & 63 & 22 & 144 & 147 \\
\hline 6 & 5 & 10 & 11 & 0 & $\mathrm{am}$ & 64 & 21 & 149 & 152 \\
\hline 6 & 5 & 10 & 2 & 0 & $\mathrm{pm}$ & 64 & 21 & 153 & 156 \\
\hline 6 & 5 & 10 & 5 & 0 & $\mathrm{pm}$ & 62 & 21 & 156 & 164 \\
\hline 7 & 5 & 10 & 7 & 0 & am & 64 & 22 & 161 & 164 \\
\hline 7 & 5 & 10 & 9 & 0 & $\mathrm{am}$ & 63 & 21 & 162 & 164 \\
\hline 7 & 5 & 10 & 1 & 30 & $\mathrm{pm}$ & 64 & 22 & 163 & 165 \\
\hline 7 & 5 & 10 & 3 & 30 & $\mathrm{pm}$ & 62 & 22 & 164 & 166 \\
\hline 8 & 5 & 10 & 10 & 0 & $\mathrm{am}$ & 62 & 22 & 166 & 168 \\
\hline 8 & 5 & 10 & 4 & 0 & $\mathrm{pm}$ & 64 & 21 & 167 & 168 \\
\hline 9 & 5 & 10 & 4 & 0 & $\mathrm{pm}$ & 63 & 22 & 168 & 170 \\
\hline 9 & 5 & 10 & 9 & 0 & $\mathrm{pm}$ & 64 & 21 & 168 & 170 \\
\hline 10 & 5 & 10 & 8 & 0 & am & 64 & 21 & 169 & 170 \\
\hline 10 & 5 & 10 & 1 & 0 & $\mathrm{pm}$ & 64 & 21 & 169 & 170 \\
\hline 10 & 5 & 10 & 5 & 0 & $\mathrm{pm}$ & 63 & 22 & 169 & 170 \\
\hline 11 & 5 & 10 & 8 & 30 & am & 63 & 22 & 170 & 171 \\
\hline 11 & 5 & 10 & 12 & 0 & $\mathrm{pm}$ & 64 & 21 & 170 & 171 \\
\hline 11 & 5 & 10 & 2 & 0 & $\mathrm{pm}$ & 62 & 22 & 170 & 171 \\
\hline 11 & 5 & 10 & 5 & 30 & $\mathrm{pm}$ & 62 & 21 & 170 & 171 \\
\hline 12 & 5 & 10 & 8 & 30 & $\mathrm{am}$ & 63 & 21 & 170 & 171 \\
\hline 12 & 5 & 10 & 1 & 30 & $\mathrm{pm}$ & 64 & 22 & 170 & 171 \\
\hline
\end{tabular}




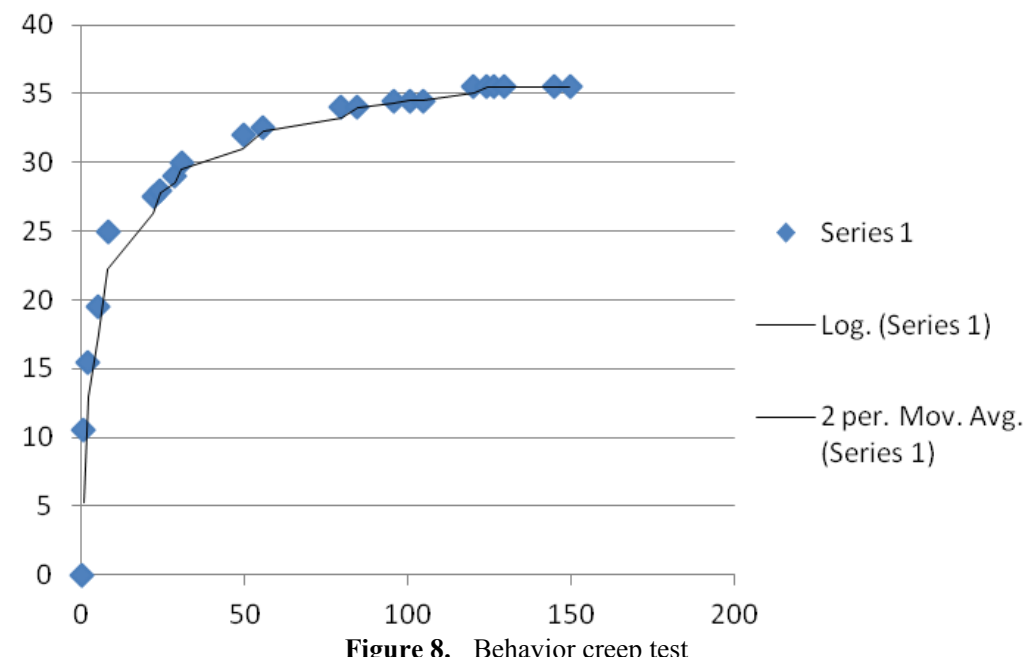

Table 5. Final Results

\begin{tabular}{|c|c|c|c|c|c|c|c|c|c|c|c|c|c|c|}
\hline \multirow[b]{2}{*}{ Specie } & \multicolumn{2}{|c|}{ Combination } & \multirow{2}{*}{$\begin{array}{l}\text { Delamination } \\
\qquad(\%)\end{array}$} & \multirow[b]{2}{*}{ fvo(MPa) $12 \%$} & \multirow[b]{2}{*}{$\mathrm{SD}$} & \multicolumn{3}{|c|}{ Shear } & \multirow[b]{2}{*}{ SD } & \multirow[b]{2}{*}{$\mathrm{CV}$} & \multirow[b]{2}{*}{$\mathrm{BM}$} & \multirow{2}{*}{\multicolumn{3}{|c|}{ Creep }} \\
\hline & Adhesive & Treatment & & & & $\mathrm{CV}$ & $\mathrm{BM}$ & $\begin{array}{l}\text { fvo(MPa) } \\
\text { Saturated }\end{array}$ & & & & & & \\
\hline \multirow{8}{*}{ Pinus } & \multirow{4}{*}{ Purbond } & NO & 0.5 & 7.03 & 0.87 & 12.38 & Wood & 3.11 & 0.45 & 14.60 & Wood & $\mathrm{X}$ & $\sqrt{ }$ & - \\
\hline & & $\mathrm{CCA}$ & 0.0 & 4.93 & 0.44 & 9.02 & Wood & 2.62 & 0.28 & 10.64 & Wood & - & - & - \\
\hline & & $\mathrm{CCB}$ & 0.7 & 5.82 & 1.17 & 20.09 & Wood & 2.59 & 0.69 & 26.74 & Wood & - & - & - \\
\hline & & CCBS & 0.1 & 5.01 & 0.23 & 4.69 & Wood & 2.93 & 0.15 & 4.95 & Wood & - & - & - \\
\hline & \multirow{4}{*}{ Cascophen } & NO & 0.6 & 5.63 & 0.46 & 8.17 & Wood & 4.09 & 0.24 & 5.92 & Wood & $\mathrm{X}$ & $\sqrt{ }$ & - \\
\hline & & $\mathrm{CCA}$ & 0.7 & 5.76 & 0.45 & 7.84 & Wood & 4.10 & 0.51 & 12.56 & Wood & - & - & - \\
\hline & & $\mathrm{CCB}$ & 0.6 & 7.05 & 0.40 & 5.60 & Wood & 4.86 & 0.65 & 13.44 & Wood & - & - & - \\
\hline & & CCBS & 0.0 & 7.73 & 1.07 & 13.81 & Wood & 5.97 & 0.95 & 15.84 & Wood & - & - & - \\
\hline \multirow{8}{*}{ Teak } & \multirow{4}{*}{ Purbond } & NO & 1.9 & 4.77 & 1.11 & 23.19 & Wood & 5.65 & 1.29 & 22.89 & Wood & $\mathrm{X}$ & $\sqrt{ }$ & $\mathrm{X}$ \\
\hline & & $\mathrm{CCA}$ & 2.8 & 6.78 & 0.72 & 10.60 & Wood & 4.95 & 1.08 & 21.89 & Wood & $\sqrt{ }$ & - & - \\
\hline & & $\mathrm{CCB}$ & 0.6 & 4.91 & 1.45 & 29.56 & $70 \% \mathrm{Ad}$ & 4.09 & 0.90 & 21.95 & Wood & $\sqrt{ }$ & - & - \\
\hline & & CCBS & 0.0 & 7.23 & 0.29 & 4.05 & Wood & 5.02 & 1.47 & 29.40 & Wood & - & - & - \\
\hline & \multirow{4}{*}{ Cascophen } & $\mathrm{NO}$ & 2.2 & 6.82 & 0.43 & 6.29 & Wood & 6.06 & 0.38 & 6.29 & Wood & $\mathrm{X}$ & $\mathrm{X}$ & $\mathrm{X}$ \\
\hline & & CCA & 0.0 & 5.98 & 0.60 & 10.03 & Wood & 3.10 & 1.03 & 33.14 & Wood & $\sqrt{ }$ & - & - \\
\hline & & $\mathrm{CCB}$ & 0.0 & 7.61 & 1.17 & 15.44 & Wood & 3.81 & 1.54 & 40.36 & Wood & $\sqrt{ }$ & $\sqrt{ }$ & - \\
\hline & & CCBS & 0.0 & 7.06 & 0.93 & 13.11 & Wood & 3.39 & 0.08 & 2.26 & Wood & - & - & - \\
\hline \multirow{8}{*}{ Lyptus } & \multirow{4}{*}{ Purbond } & $\mathrm{NO}$ & 38.1 & 3.40 & 0.21 & 6.23 & Wood & 2.64 & 1.09 & 41.20 & $50 \%$ & $\mathrm{X}$ & - & - \\
\hline & & CCA & 7.6 & 5.45 & 0.82 & 15.03 & $70 \% \mathrm{Ad}$ & 3.54 & 0.78 & 22.02 & Ad & - & - & - \\
\hline & & $\mathrm{CCB}$ & 4.7 & 3.13 & 0.49 & 15.80 & Wood & 1.66 & 0.37 & 22.06 & $50 \%$ & - & - & - \\
\hline & & CCBS & 7.2 & 3.61 & 0.92 & 25.35 & $70 \% \mathrm{Ad}$ & 2.64 & 0.58 & 21.86 & $50 \%$ & - & - & - \\
\hline & \multirow{4}{*}{ Cascophen } & $\mathrm{NO}$ & 38.6 & 4.10 & 0.98 & 23.95 & Wood & 2.03 & 0.59 & 28.87 & $50 \%$ & $\sqrt{ }$ & $X$ & - \\
\hline & & CCA & 11.1 & 2.77 & 1.02 & 36.84 & $70 \% \mathrm{Ad}$ & 1.21 & 0.39 & 31.99 & $\mathrm{Ad}$ & - & - & - \\
\hline & & CCB & 8.3 & 3.37 & 1.07 & 31.73 & Wood & 2.47 & 1.27 & 51.47 & $\mathrm{Ad}$ & - & - & - \\
\hline & & CCBS & 8.9 & 3.96 & 1.37 & 34.47 & $70 \% \mathrm{Ad}$ & 2.54 & 0.00 & 0.04 & $50 \%$ & - & - & - \\
\hline
\end{tabular}

DP: standard deviation

CV: Coefficient of variation

BM: Break Mode 


\section{Conclusions}

The control system of quality wood and engineered wood products must be immediately implemented for the successful use of the material. Considering the experience in the use of international standards on the subject and globalization, auditing standards should be based on international standards and adapted to the conditions and domestic materials. The proposed methodologies presented for the tests were satisfactory for the classification of the use class combinations for species-adhesive-preservative treatment.

The Combination that showed the best performance was pine wood with any type of adhesive or treatment discussed can be well used in external mode (outdoors). Lyptus wood, for any combination adhesive-treatment fell in the class internal use. Teak wood can be used indoors (PURBOND adhesive and all types of treatment) and outdoors (Cascophen adhesive and all types of treatment).

The processing and handling of materials and adhesive species require a very strict quality control, as these materials are very sensitive to variations in humidity, temperature, time and pressure.

\section{ACKNOWLEDGEMENTS}

I would like to acknowledge and extend my heartfelt gratitude to the LaMEM, all its employs, all the industries that support us and FIPAI for the scholarship provided.

\section{REFERENCES}

[1] American Institute of Timber Construction. Test T122 Mix Ratio. Check for Automatic Adhesive Mixing Machines. Colorado, 2004.

[2] American Institute of Timber Construction. Test T123 Sampling. Testing and Data Analysis to Determine Tensile
Properties of Lumber. Colorado, 2004.

[3] American Institute of Timber Construction. Standard for Alternate Lumber Grades for Use in Structural Glued Values. Colorado, 2005.

[4] Calil Neto, C. Recomendações para o controle de qualidade na produção de madeira laminada colada (MLC) certificada. Trabalho de final de curso - UNESP, Itapeva, 2008.

[5] FERGON. Eucalypto Lyptus - A Natureza agradece. Artigo técnico. Disponível em HTTP:// http://www.fergontopseg.co m.br/Eucalipto_Lyptus.asp, 2008.

[6] Charles B. Vick. Coupling agent improves durability of PRF bonds to CCA-treated. Science Direct, 1995.

[7] Associação Brasileira de Normas Técnicas ABNT NBR 7190. Projeto de estruturas de Madeira, Rio de Janeiro, 2011.

[8] Ross, R. J.; Pellerin, R. F. Nondestructive testing for assessing wood members in structures. Gen. Tech. Rep. FPL-GTR-70 USDA, Department of Agriculture, Forest Service, Madison, WI.42 p., 1994.

[9] American National Standard for Wood Products (AITC). 2007. Structural Glued Laminated Timber. AITC A190 Colorado

[10] Canadian Standards Association Qualification Code for Manufactures of Structural Glued - Laminated Timber. p 16, 2006.

[11] Pizzi, A. Advanced wood adhesives technology. New York: Marcel Dekker 297 p., 1994.

[12] Sellers JR., T. Wood adhesive innovation and applications in North America. Forest Products Journal, Madison, v. 51, n. 6, p.12-22, 2001.

[13] Albuquerque, C. E. C. et al. Colagem varia de acordo com propriedades da madeira. Revista da Madeira, São Paulo. Ed. 88 mar., 2005.

[14] European Standards. 386 Glued Laminated Timber: performance requirements and minimum production requirements. p 14, 2011. 